\title{
A hat legnagyobb latin-amerikai ország exportjának vizsgálata gravitációs modellel*
}

\section{Pösténụi Andrea,}

a Debreceni Egyetem

PhD-hallgatója

E-mail:

andrea.postenyi@gmail.com
A tanulmány a hat legnagyobb latin-amerikai ország, Argentína, Brazília, Chile, Kolumbia, Mexikó és Peru exportjának gravitációs modellel történő elemzésével foglalkozik. A vizsgálat célja ezen országok exportját leginkább befolyásoló tényezők meghatározása, kiemelt figyelmet szentelve a regionális kereskedelmi integrációk hatásának. Az OECD- és nem OECDpartnerekkel folytatott bilaterális kereskedelemben, valamint a bővített minta alapján a világátlagtól is jelentős exporteltérések mutatkoznak, föként a földrajzi távolság, közös nyelv és szabadkereskedelmi megállapodás terén.

TÁRGYSZÓ:

Külkereskedelem.

Latin-Amerika.

Gravitációs modell.

DOI: 10.20311/stat2017.02.hu0166

* A tanulmány a szerző „A 6 legnagyobb latin-amerikai ország külkereskedelmének vizsgálata gravitációs modellel” címü doktori disszertációja alapján készült (Pöstényi [2016]). 


\begin{abstract}
A latin-amerikai országok számos hasonló gazdasági, politikai és történelmi jellemzővel rendelkeznek, napjainkban viszont mégis jelentős különbségeket fedezhetünk fel, melyeket föként az utóbbi 30-40 év reformjai, illetve azok kudarcai okoznak. Az elmúlt évtizedekben végrehajtott modernizációs kísérletek eredményeként fellendülések és recessziók időszakát élte a térség: az 1970-es évekre bizonyossá vált, hogy a desarrollismo (modernizáció) ${ }^{1}$ kísérlete minden latin-amerikai országban elbukott, az 1980-as éveket az ,elveszett évtizednek” tekinthetjük, az 1990-es években a strukturális reformoknak köszönhetően lassú stabilizáció kezdődött, majd a 2000-es évektől a kivételes gazdasági környezetnek és a belső reformoknak köszönhetően látványos gazdasági fejlődés következett be, melynek csupán a 2007-2009-es világgazdasági válság vetett véget (Anderle [2010]). A XX. század második felében a GATT (General Agreement on Tariffs and Trade - Általános Vám- és Kereskedelmi Egyezmény) és a WTO (World Trade Organization - Kereskedelmi Világszer-

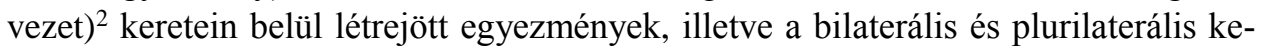
reskedelmi megállapodások, valamint az unilaterális kereskedelmi nyitás következtében a vám és nem vámjellegủ akadályok jelentős mértékủ csökkenésének lehettünk tanúi, mellyel párhuzamosan a világkereskedelem soha nem látott méreteket öltött.

A tanulmányban gravitációs modellel vizsgálom a hat legnagyobb LAC- (Latin America and the Caribbean - latin-amerikai és karibi) ország, Argentína, Brazília, Chile, Kolumbia, Mexikó és Peru exportját az 1995 és 2012 közötti időszakban, nagy hangsúlyt helyezve a bilaterális exportra hatással levő tényezőkre. A vizsgálat fö kutatási kérdésköre, hogy a LAC6-országok exportját adott tényezök miként befolyásolják, ezek mennyiben térnek el a világátlagtól, illetve kiemelt szerepet kap a regionális megállapodások kereskedelemre gyakorolt hatása.
\end{abstract}

\title{
1. A külkereskedelem gravitációs modellje
}

A második világháborút követő gazdasági fellendülés időszaka jelentős kereskedelempolitikai változásokat indított el világszerte: a nemzetközi kereskedelem libera-

\footnotetext{
${ }^{1}$ Ez a kísérlet magában foglalta a nemzetgazdaságok dinamizálására, a külföldi tőkétől és a világgazdaságtól való függés enyhítésére, a társadalomban kialakult szakadék csökkentésére, a mezőgazdaság modernizálására vonatkozó erőfeszítéseket (Anderle [2010] 129. old.).

${ }^{2}$ A GATT 1947-ben jött létre, célja a világkereskedelem liberalizálása, a vámok és nem vámjellegü korlátok csökkentése, illetve felszámolása volt. Állandó szervezetként ezt a megállapodást váltotta fel 1995-ben a WTO.
} 
lizációja először a GATT/WTO közremüködésével multilaterális alapon kezdődött, majd az 1980-as évektöl egyre inkább elterjedtek a különféle preferenciális és szabadkereskedelmi megállapodások. Számuk növekedésével párhuzamosan jelentősen bővült a kereskedelem vizsgálatával kapcsolatos elméleti, majd ezt követően az empirikus modellek száma is. Anderson [2010] szerint mindezek sorában az egyik legjelentősebb és empirikusan legsikeresebb modell a külkereskedelem gravitációs elmélete. A kereskedelmi gravitációs modell a bilaterális kereskedelem alakulását a GDP és a földrajzi távolság nagyságával, valamint számos hatótényezővel (a kereskedelmi korláttal, a közös nyelvvel, határral és kereskedelmi megállapodással) kapcsolja össze. A kereskedelmi adatok hozzáférhetőségének javulása, illetve a számítási korlátok csökkenése mellett a modell népszerüségét növeli magyarázó erejének nagysága is, mivel a legtöbb esetben az $R^{2} 60-80$ százalék között mozog (Head [2003]).

A külkereskedelem gravitációs modellje a fizikából már jól ismert egyenletből indul ki, melyet Isaac Newton 1687-ben fogalmazott meg az általános tömegvonzás törvényeként. Az egyenlet alapján a gravitációs kölcsönhatás nagysága egyenesen arányos a kölcsönhatásban levő két test tömegének szorzatával és fordítottan arányos az objektumok távolságának négyzetével (Head [2003]). A gravitációs modellt a társadalomtudományok területén először a XIX. század végén alkalmazták, habár ekkor a modell még nem volt formalizált. Ravenstein [1889] cikkében a XIX. században kirajzolódó migrációs mintákat vizsgálta, és megfigyelte, hogy az emberek országok közötti mozgása hasonlatos a fizikából akkor már jól ismert gravitációs modell által leírt törvényszerüségekhez.

A gravitációs modellt kereskedelmi empirikus vizsgálathoz először Tinbergen [1962] használta, és megállapította, hogy a kereskedelem optimális szintjét leginkább meghatározó tényező a két ország gazdaságának mérete GNP (gross national product bruttó nemzeti termék), valamint a közötttük fennálló távolság. Az importáló ország GNP-je egyrészt jelzi az ország keresletének nagyságát, másrészt pedig az előállított termékeinek diverzitását. Ezen kettős hatás miatt egységnél kisebb hatást várunk a gazdasági méret esetében, ugyanis minél inkább diverzifikált egy adott országban az előállított termékek köre, annál kevésbé lesz szüksége importra, tehát az importáló ország GNP-jének növekedésével párhuzamosan ceteris paribus egységnél kisebb mértékben fog növekedni az importja. Az exportáló ország gazdasági mérete jól jelzi az ország képességét exportálható termékek előállítására, így a GNP növekedése az exportáló ország esetében is pozitívan korrelál a kereskedelem nagyságával. A földrajzi távolság abból a nyilvánvaló okból van hatással a kereskedelem nagyságára, hogy az áruk mozgatása országok között költségekkel jár. Minél többet kell utaznia egy terméknek, annál több költség merül fel a szállítással kapcsolatban, így a távolság negatív hatással van az importra. Ezt követően számos további empirikus tanulmány - mint például Linnemann [1966] és Aitken [1973] - született a kereskedelem gravitációs modelljét alkalmazva, azonban ezek még nem rendelkeztek szilárd elméleti alapokkal. 
A gravitációs modell elméleti alapjai Tinbergen [1962] vizsgálódását követően bő másfél évtizeddel később jelentek meg Anderson [1979] nyomán. Tanulmányában a gravitációs egyenlet a következő általános formában jelenik meg:

$$
M_{i j k}=\alpha_{k} Y_{i}^{\beta_{k}} Y_{j}^{\gamma_{k}} N_{i}^{\varepsilon_{k}} N_{j}^{\xi_{k}} d_{i j}^{\mu_{k}} U_{i j k},
$$

ahol $M_{i j k} k$ jószág vagy tényező $i$ országból vagy régióból $j$ országba vagy régióba történő áramlása dollárban kifejezve, $Y_{i}$ és $Y_{j} i$ és $j$ ország vagy régió jövedelme, $N_{i}$ és $N_{j} i$ és $j$ ország vagy régió lakossága, $d_{i j} i$ és $j$ ország vagy régió közötti távolság, $U_{i j k}$ pedig lognormális eloszlású hibatag, melynek várható értéke 0 . A gravitációs egyenlet szerint a bilaterális kereskedelem a gazdaság és lakosság méretén kívül az $i$ és $j$ ország vagy régió közötti bilaterális kereskedelmi akadályoktól is függ, melyet földrajzi távolsággal szokás közelíteni. Minél magasabbak a korlátok $j$ ország és más kereskedelmi partnerei között, annál inkább nő az $i$ országból érkező import. Két ország kereskedelme az egymás közötti bilaterális akadályok és a más kereskedelmi partnerekkel kapcsolatos többoldalú kereskedelmi akadályok (multilateral resistance) viszonyától függ. Kisebb országok számára a külkereskedelem fontosabb, ezért ezekben a kereskedelmi akadályoknak jelentősebb a hatásuk (Anderson-van Wincoop [2001]).

Az elméleti alapok megjelenését követően a gravitációs modell a külkereskedelmi vizsgálatok legsikeresebb empirikus módszerévé vált. Az empirikus vizsgálatok olyan tényezők kereskedelemre gyakorolt hatását mérték, mint például a szomszédosság (McCallum [1995], Wei [1996], Anderson-van Wincoop [2001], MayerZignago [2005]); a tényezőellátottság (Rahman [2003], Schumacher [2003], Sohn [2005], Eicher-Henn-Papageorgiou [2012], Shirotori-Tumurchudur-Cadot [2010]); a közös nyelv és gyarmati kötelék (Hutschinson [2002], Head-Mayer-Ries [2010], Oh-Selmier-Lien [2011], Felbermayr-Toubal [2007], Martinez-Zarzoso [2003]); az intézmények és korrupció (Anderson-Marcouiller [2002], de Groot et al. [2004]); a szabadkereskedelmi egyezmények és a regionális integrációk (Martinez-Zarzoso [2003], Baier-Bergstrand [2007], Carrere [2006], Soloaga-Winters [2001], Jugurnath-Stewart-Brooks [2007], Coulibaly [2009], Anderson-Yotov [2011], Rose-van Wincoop [2001], Vicard [2009], Frankel-Wei [1998]).

A gravitációs modellel kapcsolatos empirikus vizsgálat eredményeinek bemutatása előtt célszerü kitérni az alapmodell és a bővített modell változóinak alapvető tulajdonságaira. A tipikus gravitációs modell függő változója a bilaterális kereskedelem (export, import vagy teljes kereskedelem) logaritmusa, magyarázóváltozói pedig a GDP, a népesség és a kereskedelmi költségek (földrajzi távolság) logaritmusa. További változók hozzáadása is szükséges az elemzés céljától függően, azonban 
magyarázó erejükkel ellentétben ezen változók modellbe illesztése helyenként kevés elméleti megalapozottsággal rendelkezik (Anderson [2010]).

Jövedelem. A jövedelem (GDP) nagysága mind az export, mind pedig az import esetében pozitívan korrelál a kereskedelem nagyságával. Exportáló országot tekintve a magas jövedelem jelentős termelést, míg az importáló országnál magas importot jelez elöre, hiszen növeli egyrészről az exportálható javak mennyiségét, másrészt pedig a keresletet. Mindezek alapján exportáló és importáló ország tekintetében is pozitív elöjelet várunk a jövedelemhez tartozó együttható esetében (MartinezZarzoso [2003]). A koefficiens értéke általában 1-hez közeli, azonban nem szokatlan 0,7 és 1,1 közé eső értékeket kapni (Head [2003]).

Népesség. Az exportáló ország népességének koefficiense pozitív és negatív is lehet attól függően, hogy a következők közül mely hatás érvényesül: a nagy ország kevesebbet fog exportálni, amennyiben az ország esetében az abszorpciós hatás (a belső piac elszívó hatása) dominál; vagy a nagy ország többet fog exportálni a kis országnál méretgazdaságossági előnyök következtében. Hasonlóképp alakul az importáló ország népességének koefficiense is (Martinez-Zarzoso [2003]). A jövedelem és népesség hányadosaként képzett egy före jutó jövedelmet is szokás változóként használni, amely jól közelíti az adott ország fejlettségi szintjét.

Távolság. A kereskedelmi akadályok közelítésére szolgáló egyik változó. Empirikus vizsgálatok szerint, ha a távolság kétszeresére nő, akkor a kereskedelem megfeleződik. A távolság viszonylag jól közelíti a kereskedelmi költségeket, a rakodás közben eltelt időt, valamint a tranzakciós és kommunikációs költségeket (Head [2003]). Habár a fizikai távolság használata jelentős torzulásokhoz vezethet, hiszen önmagában nem képes minden kereskedelmi akadályt megragadni, alkalmazása mégis általánosan elfogadott, mivel nagyon nehéz a kereskedelmi akadályokat közvetlenül mérni.

Kulturális affinitás. Egyre több tanulmány szerint a bilaterális kereskedelem meghatározó tényezöje a kulturális közelség, melyet olyan mutatókkal közelítenek, mint például a nyelvi hasonlóság, gyarmati kapcsolatok, vallási, etnikai és biológiai hasonlóságok. Alapvetően két csatornán keresztül hat a kulturális közelség a bilaterális kereskedelemre. Elöször is a kulturális hasonlóság csökkenti a közvetlen és közvetett kereskedelmi költségeket, például a közös nyelv közvetlenül csökkenti a tranzakciós költségeket, mivel nem szükséges tolmács alkalmazása. Hasonlóképp csökkenti a szerződéskötés költségét, amikor a vevő és az eladó hasonló jogi és intézményi környezetből származik. A második csatorna pedig a fogyasztók preferenciáival kapcsolatos: a kulturális hasonlóság tükröződhet a fogyasztók hasonló preferenciáiban is, így közvetlenül növelheti a kereskedelem volumenét (Felbermayr-Toubal [2007]). Például Martinez-Zarzoso [2003] vizsgálata alapján két közös nyelvet beszélő ország 1999-ben 242 százalékkal többet kereskedett egymással, mint a más nyelveket beszélőkkel. A kulturális változókat dummy változóval fejezik ki, például 
nyelv esetén, ha a két országnak van közös hivatalos nyelve, akkor a változó 1-et vesz fel, ha pedig nincs, akkor 0-át.

Szomszédosság. Szintén dummy változó, mely 1 értéket veszi fel, ha két országnak van közös határa. A koefficiens általában pozitív elöjelü, közös határ megléte esetén a két ország közötti kereskedelem átlagosan 65 százalékkal magasabb (Head [2003]).

Regionális kereskedelmi egyezmény. A modellben a kereskedelmi egyezmény is dummy változóként jelenik meg, alapvetően 1 értéket veszi fel, ha mindkét ország részese az adott egyezménynek, 0 -át pedig, ha nem. Általában pozitív együtthatót várunk, hiszen ezek az egyezmények kereskedelmet könnyítő tényezők, ezáltal pedig növelik az adott országok külkereskedelmét. Számos különbséget figyelhetünk meg az empirikus tanulmányokban mind a használt változók tekintetében, mind pedig az empirikus eredményeket nézve. Például Baier-Bergstrand [2007] eredményei alapján egy RTA (regional trade agreement - regionális kereskedelmi egyezmény) átlagosan 86 százalékkal növeli két tagországának kereskedelmét. Ezzel szemben Martinez-Zarzoso [2003] szerint nem minden kereskedelmi egyezmény van pozitív hatással az aláíró országok kereskedelmére: eredményeik alapján például az Európai Unió és a NAFTA ${ }^{3}$ (North American Free Trade Agreement - Észak-amerikai Szabadkereskedelmi Egyezmény) szignifikáns és pozitív hatással van a tagországok kereskedelmére, azonban a CARICOM ${ }^{4}$ (Caribbean Community - Karib-tengeri Közösség) és CACM (Central American Common Market - Közép-amerikai Közös Piac) ${ }^{5}$ hatása a tagországokra a nyolcvanas éveket kővetően inszignifikánssá vált. Carrere [2006] hét RTA hatását vizsgálta, és úgy találta, hogy összességében ezek szignifikánsan növelték a tagországok közötti kereskedelmet, azonban általában más kereskedelmi partnerek kárára. Shujiro-Misa [2007] 63 ország kereskedelmét vizsgálták az 1990 és 2005 közötti időszakra, és azt találták, hogy aggregált szinten a szabadkereskedelmi megállapodások kereskedelemteremtő hatásokkal ${ }^{6}$ járnak, a kereskedelemterelő hatás termékek szintjén mutatkozik csak meg az EU, a NAFTA és a Mercosur ${ }^{7}$ (Mercado Común del Sur - Dél-amerikai Közös Piac) esetében.

\footnotetext{
${ }^{3}$ Kanada, Egyesült Államok, Mexikó.

${ }^{4}$ Antigua és Barbuda, Bahama-szigetek, Barbados, Belize, Dominikai Köztársaság, Grenada, Guyana, Haiti, Jamaica, Montserrat, Saint Kitts és Nevis, Saint Lucia, Saint Vincent és a Grenadine-szigetek, Suriname, Trinidad és Tobago.

${ }^{5}$ Guatemala, El Salvador, Honduras, Nicaragua.

${ }^{6}$ Alapvetően a kereskedelmi egyezmények megkötésekor pozitívak a várakozások a nettó hatások tekintetében, az integráción belüli és kívüli országokat tekintve azonban egyszerre járhatnak pozitív és negatív hatásokkal is, a Viner [1950] megközelítése alapján beszélhetünk kereskedelemteremtő, illetve kereskedelemterelő hatásokról. Kereskedelemteremtő hatás akkor jelentkezik, amikor a kereskedelmi akadály eltörlése a nemzetközi munkamegosztás bővülését teszi lehetővé, az integrációs tagországok együttesen jobb helyzetbe kerülnek az új komparatív előnyök révén. Kereskedelemterelő hatás akkor jelentkezik, ha az integráció létrejöttével egy korábbi alacsony költséggel elóállító országtól egy magasabb költséggel termelő - ám kereskedelmi akadályokkal nem szembesülő - integrációs országba terelődik át a kereskedelem iránya.

${ }^{7}$ Argentína, Brazília, Paraguay, Uruguay, Venezuela.
} 


\section{A LAC6-országok exportjának vizsgálata gravitációs modellel}

A tanulmány a továbbiakban az empirikus kutatást ismerteti (Pöstényi [2016]). A vizsgálat során levont következtetések természetesen ceteris paribus értendők.

\subsection{Adatok}

Az exportadatok az ENSZ Comtrade (https://comtrade.un.org) adatbázisából (SITC Rev. 3) származnak. Számos gravitációs empirikus tanulmány szektorális adatokkal számol, azonban az elmélet nem mondja ki, hogy a gravitációs modell előrejelzéseinek szektorok szintjén is érvényesülniük kellene, így a modellbe aggregált adatok kerültek.

A 2000. évi dolláron számított változatlan áras GDP és a népességi adatok a Világbank World Development Indicators (World Bank WDI) adatbázisából származnak.

A közös határ, nyelv és a távolság változók a CEPII (Centre d'Études Prospectives et d'Informations Internationales - Nemzetközi Jövőkutatási és Tájékoztatási Központ) gravitációs adattáblájából (www.cepii.fr) származnak. Vizsgálatom során a közös hivatalos nyelvet vettem figyelembe (ugyanis a hivatali ügyintézés során elhanyagolható a szerepe annak, ha egy adott országban egy nagyobb kisebbség beszéli egy másik ország nyelvét), valamint a fővárosok közötti távolságot.

A kereskedelmi egyezmények a WTO adatbázisából származnak, figyelembe vettem minden olyan szabadkereskedelmi megállapodást, illetve annál mélyebb szintü integrációs szerződést, mely bilaterális vagy plurilaterális alapon kötődött a vizsgált időszak alatt, és a javak szabadabb áramlását tüzte ki célul.

A vizsgálat során az $i$ ország a LAC6-országok egyikét, a $j$ ország pedig ezen $i$ ország kereskedelmi partnerét jelöli. Annak érdekében, hogy a lehető legkevesebb torzítás legyen a modellben, csak olyan országpárok kerültek a vizsgálatba, melyek esetében minden évre hiánytalanul volt elérhető adat. Ezáltal a modell a tartós kereskedelmi kapcsolatok főbb tényezőit magyarázza, és így az ad hoc jellegü kereskedelmi kapcsolatok nincsenek rá torzító hatással.

Az empirikus vizsgálat az 1995 és 2012 közötti időszakra terjed ki. 1995 volt az első olyan év, amikor mind a LAC6-országok, mind pedig a kereskedelmi partnerek tekintetében a legtöbb országra vonatkozóan volt elérhető adat (gondoljunk csak a volt szocialista országok kereskedelmi és gazdasági statisztikáira a rendszerváltást követő első években), 2012 pedig azért lett az időintervallum felső határa, mivel erre az évre vonatkozóan volt a kiválasztott országok mindegyikére elérhető gazdasági és kereskedelmi adat a vizsgálat elvégzésének idején. A LAC6-országok exportját vizsgáló minta 407 országpár adatait tartalmazza, így a megfigyelések száma 7 326, a bővített mintában esetében 4997 országpár szerepel és a megfigyelések száma 
89 244. Az empirikus vizsgálatban szereplő országok listája az M1. és M2. internetes mellékletben található (www.ksh.hu/statszemle).

\subsection{Modellspecifikációk}

A LAC6-országok exportját panel segítségével vizsgáltam, az empirikus vizsgálatot a STATA/MP 13.0 statisztikai programmal végeztem el. Annak érdekében, hogy minél pontosabb következtetéseket lehessen levonni, a mintát számos modellspecifikáció használatával vizsgáltam, a kiindulási alap a gravitációs alapmodell természetes alapú logaritmusa volt:

$$
\ln \text { Export }_{i j t}=\alpha_{0}+\alpha_{1} \ln G D P_{i t}+\alpha_{2} \ln G D P_{j t}+\alpha_{3} \ln D I S T_{i j}+e_{i j t},
$$

ahol Export $_{i j t} i$ és $j$ ország közötti exportot fejezi ki a $t$ évben, $G D P_{i t}$ és $G D P_{j t} i$ és $j$ ország gazdasági mérete a $t$ évben, $D I S T_{i j} i$ és $j$ ország közötti földrajzi távolság, $e_{i j t}$ pedig a lognormális eloszlású hibatag zérus várható értékkel. Az alapmodell arra a kérdésre ad választ, hogy a minta esetében a kereskedelem mekkora részét lehet magyarázni a gazdasági mérettel és az országok közötti távolságokkal, illetve ezen tényezők milyen irányú és mekkora hatással vannak az exportáló országok kereskedelmére.

Második lépésként az alapmodellt népességi változókkal egészítettem ki, hogy ezáltal megragadhassuk az exportőr és importőr országok lakosságának kereskedelemre gyakorolt hatását:

$$
\begin{aligned}
\ln \text { Export }_{i j t} & =\alpha_{0}+\alpha_{1} \ln G D P_{i t}+\alpha_{2} \ln G D P_{j t}+\alpha_{3} \ln D I S T_{i j}+\alpha_{4} \ln P O P_{i t}+, \quad, 3 / \\
& +\alpha_{5} \ln P O P_{j t}+e_{i j t}
\end{aligned}
$$

ahol $P O P_{i t}$ és $P O P_{j t} i$ és $j$ ország lakosságát fejezi ki $t$ évben.

Ezt követően a modellt az empirikus irodalomban leggyakrabban használatos bináris (dummy) változókkal egészítettem ki:

$$
\begin{aligned}
\ln \text { Export }_{i j t} & =\alpha_{0}+\alpha_{1} \ln G D P_{i t}+\alpha_{2} \ln G D P_{j t}+\alpha_{3} \ln D I S T_{i j}+\alpha_{4} \ln P O P_{i t}+ \\
& +\alpha_{5} \ln P O P_{j t}+\beta_{1} C O N T_{i j}+\beta_{2} C O M L A N G_{i j}+\beta_{3} F T A_{i j t}+e_{i j t}
\end{aligned}
$$

ahol $C O N T_{i j}$ a két ország közötti közös határ, $C O M L A N G_{i j}$ pedig a közös nyelv meglétét megragadó bináris változó. $F T A_{i j t}$ a szabadkereskedelmi megállapodást ragadja meg $t$ évre vonatkozóan. 
Ország- és időspecifikus dummy változók is bekerültek a későbbiekben a modellbe, mely modellbővítések célja nem csupán az, hogy megragadjunk minden olyan kereskedelmet befolyásoló tényezőt, melyet nem fednek le a bemutatott egyenletek változói, hanem a szakirodalomból jól ismert többoldalú kereskedelmi akadályok kiszürése is annak érdekében, hogy minél kevésbé torzított eredményeket kapjunk.

A modellekhez tartozó leíró statisztikák az M3. és M4. mellékletben találhatók.

\subsection{Eredmények a LAC6-országokra vonatkozóan}

Az empirikus eredményeket a LAC6-országok exportjára vonatkozóan az 1. táblázat foglalja össze.

1. táblázat

A LAC6-országok exportjának gravitációs vizsgálata

\begin{tabular}{|c|c|c|c|c|c|}
\hline \multirow{2}{*}{ Változó } & \multirow{2}{*}{ Alapmodell } & \multirow{2}{*}{$\begin{array}{c}\text { Bővített } \\
\text { alapmodell }\end{array}$} & \multicolumn{3}{|c|}{ Bővített modell } \\
\hline & & & I. & II. & III. \\
\hline $\ln G D P_{i}$ & $\begin{array}{c}0,89 * * * \\
(52,27)\end{array}$ & $\begin{array}{c}2,13 * * * \\
(43,88)\end{array}$ & $\begin{array}{c}2,12 * * * \\
(43,20)\end{array}$ & $\begin{array}{c}1,99 * * * \\
(49,62)\end{array}$ & $\begin{array}{l}1,95 \text { *** } \\
(48,15)\end{array}$ \\
\hline $\ln G D P_{j}$ & $\begin{array}{c}1,09 * * * \\
(108,85)\end{array}$ & $\begin{array}{c}1,02 * * * \\
(67,06)\end{array}$ & $\begin{array}{c}1,06^{* * * *} \\
(67,11)\end{array}$ & $\begin{array}{l}2,08 * * * \\
(17,28)\end{array}$ & $\begin{array}{l}1,61 * * * \\
(9,94)\end{array}$ \\
\hline $\ln D I S T_{i j}$ & $\begin{array}{l}-1,70 * * * \\
(-71,25)\end{array}$ & $\begin{array}{l}-1,76^{* * * *} \\
(-69,86)\end{array}$ & $\begin{array}{l}-1,25 * * * \\
(-30,24)\end{array}$ & $\begin{array}{l}-1,09 * * * \\
(-27,82)\end{array}$ & $\begin{array}{l}-1,08 * * * \\
(-27,83)\end{array}$ \\
\hline $\ln P O P_{i}$ & & $\begin{array}{l}-1,61 * * * \\
(-28,34)\end{array}$ & $\begin{array}{l}-1,52 * * * \\
(-26,41)\end{array}$ & $\begin{array}{l}-1,41 \text { *** } \\
(-30,11)\end{array}$ & $\begin{array}{l}-1,37 \text { *** } \\
(-29,08)\end{array}$ \\
\hline $\ln P O P_{j}$ & & $\begin{array}{l}0,10 * * * \\
(6,19)\end{array}$ & $\begin{array}{l}0,04 * * \\
(2,49)\end{array}$ & $\begin{array}{l}-1,17 * * * \\
(-3,48)\end{array}$ & $\begin{array}{l}-1,36 \text { *** } \\
(-3,84)\end{array}$ \\
\hline$C O N T_{i j}$ & & & $\begin{array}{l}0,82 * * * \\
(11,46)\end{array}$ & $\begin{array}{c}0,73 * * * \\
(12,99)\end{array}$ & $\begin{array}{l}0,74 * * * \\
(13,17)\end{array}$ \\
\hline$C O M L A N G_{i j}$ & & & $\begin{array}{c}0,98^{* * *} \\
(17,62)\end{array}$ & $\begin{array}{l}0,13^{* *} \\
(2,32)\end{array}$ & $\begin{array}{l}0,12 * * \\
(2,22)\end{array}$ \\
\hline$F T A_{i j}$ & & & $\begin{array}{l}-0,13 * * * \\
(-2,71) \\
\end{array}$ & $\begin{array}{l}-0,10 * * * \\
(-2,58) \\
\end{array}$ & $\begin{array}{l}-0,13 * * * \\
(-3,20)\end{array}$ \\
\hline Konstans & $\begin{array}{l}-18,54 * * * \\
(-36,16)\end{array}$ & $\begin{array}{l}-22,59 * * * \\
(-43,41)\end{array}$ & $\begin{array}{l}-28,58 * * * \\
(-45,17)\end{array}$ & $\begin{array}{c}-32,76^{* * *} \\
(-8,35)\end{array}$ & $\begin{array}{l}-17,19 * * * \\
(-2,80)\end{array}$ \\
\hline$R^{2}$ & 0,6571 & 0,6943 & 0,7061 & 0,8219 & 0,8245 \\
\hline Kiigazított $R^{2}$ & 0,6569 & 0,6940 & 0,7057 & 0,8197 & 0,8219 \\
\hline Magyarázóváltozók száma (darab) & 3 & 5 & 8 & 87 & 104 \\
\hline Megfigyelések száma (darab) & 7326 & 7326 & 7326 & 7326 & 7326 \\
\hline
\end{tabular}

Megjegyzés. A Bővített modell II. az országspecifikus dummy változókat; a Bővített modell III. az országés időspecifikus dummy változókat tartalmazza.

Itt és a továbbiakban a zárójelben a $t$-statisztikák találhatók. * 10 százalékos, ${ }^{* *} 5$ százalékos, ${ }^{* * *} 1$ százalékos szignifikanciaszinten. 
Az alapmodell eredményeit tekintve a LAC6-országok exportjának kétharmadát lehet magyarázni az alapváltozókkal. Mindhárom 1 százalékos szinten szignifikáns értéket vesz fel, a GDP koefficiensei pozitív, a távolságé pedig negatív előjelü értéket mutat, tehát a gazdasági mérettel párhuzamosan növekszik a kereskedelem értéke, miközben a távolság növekedésével csökken. A konkrét értékeket tekintve, a LAC6-országok GDP-jének 1 százalékos növekedésével exportjuk átlagosan 0,89 százalékkal bővül. A kereskedelmi partner GDP-jének 1 százalékos emelkedése esetén a LAC6-országokból származó importjuk 1,09 százalékkal nő, a távolság 1 százalékos növelésével a kereskedelem értéke 1,7 százalékkal csökken, ceteris paribus.

Amennyiben népességi változókat helyezünk a modellbe, jelentős mértékben növekszik az $i$ ország GDP-jének koefficiense, ami multikollinearitás jelenlétére utal, mindeközben a $j$ országhoz tartozó GDP és a távolság együtthatója alig módosul. A bővített alapmodell alapján a LAC6-országok népességének növekedése negatív hatással van az export méretére, azaz a LAC6-országok esetében az abszorpciós hatás ${ }^{8}$ érvényesül, vagyis a lakosság növekedésével párhuzamosan inkább nő a belső kereslet a saját termékek iránt, és ezáltal kevesebb terméket fognak ezen országok az exportpiacokra szánni. Ezzel szemben a kereskedelmi partnerek népességének gyarapodása hatására növekszik a LAC6-országokból származó termékek importja, habár ez a hatás jelentősen kisebb, mint az exportőr országok esetében. Mindezen hatások 1 százalékos szinten szignifikánsak.

A harmadik modellspecifikáció tartalmazza már a bővített modell dummy változóit is. Habár ennek magyarázóereje nem sokkal nagyobb az alapmodell értékénél, minden változó szignifikáns értéket mutat 5 százalékos szinten. Az új változók modellbe kerülésével a GDP-hez tartozó koefficiensek értéke alig változott, a dummyk hatására azonban jelentősen csökkent a távolsághoz tartozó koefficiens nagysága, amely nem meglepő, hiszen ezen bináris változók a kereskedelmet segítő és akadályozó egyéb tényezőket hivatottak megragadni. A lakossághoz tartozó együtthatók előjele és szignifikanciája nem változott a modell bővítésével, a koefficiensek nagysága azonban némileg csökkent. A bővített modell eredményei alapján a LAC6országok exportjára 1 százalékos szinten szignifikáns pozitív hatással van a közös

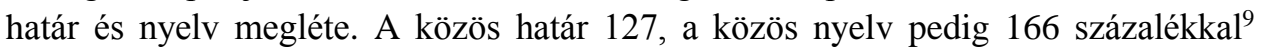
növeli a LAC6-országok exportját.

A közös kereskedelmi megállapodáshoz tartozó koefficiens 1 százalékos szinten szignifikáns értéket mutat, azonban ennek elöjele negatív. Téves lenne azonban ez alapján azt a következtetést levonni, miszerint a LAC6-országok esetében ezen meg-

\footnotetext{
${ }^{8}$ Lásd bővebben Martinez-Zarzoso [2003].

${ }^{9}$ Dummy változó esetén a koefficiens hatásának értelmezéséhez a következö összefüggést szokás használni: $100 *[\exp (X)-1]=Y \%$.
} 
állapodások aláírása számottevően csökkentené a kereskedelmet. Tekintve, hogy egyetlen változóval ragadjuk meg az összes megkötött kereskedelmi egyezmény hatását, így a végeredmény könnyen torzított lehet.

Annak érdekében, hogy az egyes országokhoz kötődő fix hatásokat is kiszürhessük és ezáltal kevésbé torzított eredményeket kapjunk, országspecifikus dummy változókkal ${ }^{10}$ egészült ki a modell. Országspecifikus dummy változók alkalmazásával jelentősen megnő a modell magyarázóereje, ugyanis ezek a bináris változók hivatottak minden, a többi változó által le nem fedett tényező hatását megragadni, melyek az egyes kereskedelmi partnerek alapján specifikusak. A modellünk kiigazított $R^{2}$-e immár közelíti a 82 százalékos értéket, miközben 5 százalékos szinten tekintve minden föbb változónk statisztikailag szignifikáns együtthatóval rendelkezik.

$\mathrm{Az}$ országspecifikus változók modellbe helyezésével jelentősen növekedett a partnerország GDP-jéhez tartozó együttható nagysága, illetve érdekes megfigyelni, hogy a távolság hatása is kevésbé jelentőssé vált. Miközben alig változott a LAC6országok népességének negatív hatása az export nagyságára, addig a partnerországok lakosságának hatása enyhe pozitív értékről határozottan negatív értékre váltott. Ezek szerint minden, a változóink által meg nem ragadott országspecifikus hatás kiszürése után negatív a kapcsolat mind a vizsgált hat ország, mind a kereskedelmi partnerei esetén a népesség növekedése és a LAC6-országokból exportált termékek értéke között. Az eredeti dummy változók közül jelentősen csökkent a közös nyelvhez tartozó együttható értéke, miközben a közös határ továbbra is szignifikáns pozitív, a közös kereskedelmi megállapodás pedig szignifikáns negatív hatást mutat.

A következő lépésben időspecifikus dummy változókkal ${ }^{11}$ egészült ki a modell annak érdekében, hogy kiszürhessük azokat a hatásokat, melyek egy-egy évre vonatkoznak. Az így kiegészült modell magyarázóereje kissé növekedett, a kiigazított $R^{2}$ 0,8219 , miközben a változók továbbra is szignifikánsak maradtak 5 százalékos szinten. Az időspecifikus tényezők modellbe helyezésével lényegi változások nem történtek a koefficiensek nagyságát és szignifikanciáját tekintve, azonban ezen dummy változók is hozzájárulnak ahhoz, hogy a lehető legkevesebb torzítást tartalmazza a modellünk.

\section{4. Érzékenységvizsgálat OECD- és nem OECD-országokkal}

Felmerül a kérdés, hogy a kapott eredmények milyen mértékben érzékenyek a mintanagyságra, illetve a minta összetételének változására. A kérdés megválaszolásához a korábbi mintát két részre bontottam az alapján, hogy a kereskedelmi partner OECD-ország vagy sem. A kapott eredményeket a 2. táblázat tartalmazza.

\footnotetext{
${ }^{10}$ A modellbe 79 dummy változó került, melyek a 79 importőr ország fix hatását hivatottak megragadni.

${ }^{11}$ A modellbe 17 dummy változó került, melyek a 18-1 év fix hatásait szürik ki.
} 
Az érzékenységvizsgálat eredményei alapján az első szembetűnő különbség az OECD- és nem OECD-országok között az $R^{2}$-ben jelenik meg: az OECDországoknál a magyarázóváltozók minden modellspecifikációt tekintve nagyobb arányban magyarázták a függő változót, mint a nem OECD-országoknál. Ez az eredmény nem meglepö, tekintve, hogy az OECD-országoknál kisebb az adatokban rejlő variancia, jobban hasonlítanak ezek az országok egymásra, mint amit a fejlődő és a közepesen fejlett országok esetében tapasztalunk.

2. táblázat

A LAC6-országok exportjának gravitációs érzékenységvizsgálata

\begin{tabular}{|c|c|c|c|c|c|c|}
\hline \multirow[t]{2}{*}{ Változó } & \multicolumn{2}{|c|}{ Alapmodell } & \multicolumn{2}{|c|}{ Bővített modell } & \multicolumn{2}{|c|}{$\begin{array}{l}\text { Bővített modell ország- } \\
\text { és időspecifikus dummy } \\
\text { változókkal }\end{array}$} \\
\hline & OECD & Nem OECD & OECD & Nem OECD & OECD & Nem OECD \\
\hline $\ln G D P_{i}$ & $\begin{array}{l}0,77 * * * \\
(34,57)\end{array}$ & $\begin{array}{l}0,98 * * * \\
(40,57)\end{array}$ & $\begin{array}{l}1,71 * * * \\
(24,92)\end{array}$ & $\begin{array}{l}2,32 * * * \\
(34,01)\end{array}$ & $\begin{array}{l}1,54 * * * \\
(27,32)\end{array}$ & $\begin{array}{l}2,22 * * * \\
(38,22)\end{array}$ \\
\hline $\ln G D P_{j}$ & $\begin{array}{l}1,28 * * * \\
(77,60)\end{array}$ & $\begin{array}{l}1,09 * * * \\
(65,40)\end{array}$ & $\begin{array}{l}1,43 * * * \\
(34,01)\end{array}$ & $\begin{array}{l}1,11 * * * \\
(34,22)\end{array}$ & $\begin{array}{l}1,11 * * * \\
(3,90)\end{array}$ & $\begin{array}{l}1,71^{* * * *} \\
(7,90)\end{array}$ \\
\hline $\ln D I S T_{i j}$ & $\begin{array}{l}-1,38 * * * \\
(-19,51)\end{array}$ & $\begin{array}{l}-1,66 * * * \\
(-59,91)\end{array}$ & $\begin{array}{l}-0,89 * * * \\
(-10,01)\end{array}$ & $\begin{array}{l}-1,22 * * * \\
(-21,84)\end{array}$ & $\begin{array}{l}-0,34 * * * \\
(-3,56)\end{array}$ & $\begin{array}{l}-1,19 * * * \\
(-26,02)\end{array}$ \\
\hline $\ln P O P_{i}$ & & & $\begin{array}{l}-1,18 * * * \\
(-14,83)\end{array}$ & $\begin{array}{l}-1,64 * * * \\
(-20,07)\end{array}$ & $\begin{array}{l}-0,97 * * * \\
(-14,61)\end{array}$ & $\begin{array}{l}-1,55^{* * * *} \\
(-23,22)\end{array}$ \\
\hline $\ln P O P_{j}$ & & & $\begin{array}{l}-0,18^{* * * *} \\
(-3,93)\end{array}$ & $\begin{array}{l}-0,06 * * \\
(-2,04)\end{array}$ & $\begin{array}{c}-1,07 \\
(-1,48)\end{array}$ & $\begin{array}{l}-1,57 * * * \\
(-3,63)\end{array}$ \\
\hline$C O N T_{i j}$ & & & $\begin{array}{l}1,67 * * * \\
(12,36)\end{array}$ & $\begin{array}{l}0,66 * * * \\
(7,69)\end{array}$ & $\begin{array}{l}1,56^{* * * *} \\
(11,62)\end{array}$ & $\begin{array}{l}0,48 * * * \\
(7,50)\end{array}$ \\
\hline$C O M L A N G_{i j}$ & & & $\begin{array}{l}1,22 * * * \\
(16,72)\end{array}$ & $\begin{array}{l}0,90^{* * *} \\
(11,44)\end{array}$ & $\begin{array}{l}0,32 * * * \\
(4,05)\end{array}$ & $\begin{array}{r}0,14 * \\
(1,72)\end{array}$ \\
\hline$F T A_{i j}$ & & & $\begin{array}{c}0,00 \\
(0,02) \\
\end{array}$ & $\begin{array}{c}0,03 \\
(0,41) \\
\end{array}$ & $\begin{array}{l}-0,12 * * \\
(-2,42) \\
\end{array}$ & $\begin{array}{l}0,12 * * \\
(1,99) \\
\end{array}$ \\
\hline Konstans & $\begin{array}{l}-23,71 * * * \\
(-22,40)\end{array}$ & $\begin{array}{l}-21,19 * * * \\
(-29,22)\end{array}$ & $\begin{array}{l}-33,58 * * * \\
(-30,21)\end{array}$ & $\begin{array}{l}-31,44 * * * \\
(-32,63)\end{array}$ & $\begin{array}{l}-14,68 \\
(-1,23)\end{array}$ & $\begin{array}{l}-18,93 * * \\
(-2,22)\end{array}$ \\
\hline$R^{2}$ & 0,7057 & 0,6186 & 0,7467 & 0,6754 & 0,8497 & 0,7987 \\
\hline Kiigazított $R^{2}$ & 0,7055 & 0,6184 & 0,7461 & 0,6747 & 0,8471 & 0,7950 \\
\hline $\begin{array}{l}\text { Magyarázóváltozók } \\
\text { száma (darab) }\end{array}$ & 3 & 3 & 8 & 8 & 58 & 70 \\
\hline $\begin{array}{l}\text { Megfigyelések száma } \\
\text { (darab) }\end{array}$ & 3438 & 3888 & 3438 & 3888 & 3438 & 3888 \\
\hline
\end{tabular}

Az alapmodellnél nem tapasztalhatunk jelentős különbséget az OECD- és a nem OECD-országokba érkező exportot befolyásoló tényezők koefficiensei tekintetében, 
viszont az $R^{2}$ esetében, amíg az OECD-országoknál az alapmodell változói az export több mint 70 százalékát tudták magyarázni, addig ez az érték a nem OECDországoknál nem éri el a 62 százalékot. A bővített modellben az $R^{2}$ közötti különbség némiképp csökkenő, azonban már jelentős eltérések mutatkoznak a magyarázóváltozók koefficiensei között is. Habár az egyes koefficiensekhez tartozó előjelek azonosak a két vizsgált csoportot tekintve, a nem OECD-országoknál jelentősebb a hatása az exportáló ország GDP-jének és népességének, miközben a távolság is jelentősebb hatással van a kereskedelemre. A közös határ ${ }^{12}$ és nyelv azonban az OECDországokkal folytatott kereskedelem esetében vesz fel magasabb értékeket, miközben a közös kereskedelmi megállapodás hatása nem szignifikáns. Mindezen eredmények alapján arra a következtetésre juthatunk, hogy - a gazdasági méret hatását kiszürve a LAC6-országok két egyforma távolságra helyezkedő ország közül az OECDországba fognak többet exportálni, épp úgy, mint a közös nyelv és közös határ meglétekor.

\section{5. Érzékenységvizsgálat bővített mintával}

Annak érdekében, hogy összehasonlíthassuk a LAC6-országok esetében kapott eredményeket más országokéval - megközelítőleg a világátlagéval -, a vizsgált mintát kibővítettem. Az új vizsgálat minden olyan országpár adatait tartalmazza, melyek az 1995 és 2012 közötti időszak éveire rendelkeztek kereskedelmi adattal (export és import adatokat külön tekintve). Mindezek alapján 79 exportőr és 81 importőr ország került a modellbe, összesen így a megfigyelések száma 89244 lett.

A 3. táblázat tartalmazza a bővített minta eredményeit a korábban ismertetett modellspecifikációk esetében. Az alap gravitációs modellben 4 százalékponttal magasabb $R^{2}$ értéket kaptam a bővített mintával, mint a LAC6-országokat tekintve, a GDP és a távolság a vizsgált minta kereskedelmének több mint 70 százalékát magyarázza már önmagában is.

A GDP-hez tartozó együtthatók esetében nem láthatunk lényeges eltérést a két minta között, a távolságot tekintve viszont a koefficiens nagysága közel megfelezödött a minta bővítésének hatására, mely alapján megállapítható, hogy a LAC6országok exportja sokkal érzékenyebb az országok közötti távolságra, mint a világ országainak átlaga. A bővített alapmodellben a népesség modellbe helyezése ezúttal sem változtatott jelentős mértékben az eredményeken, a népesség és a gazdasági méret esetében az új vizsgálat során az $i$ és $j$ országok közötti különbség a minta aszimmetriájából fakad, és így az együttes hatást érdemes figyelembe venni.

\footnotetext{
${ }^{12}$ Ebben jelentős szerepe van Mexikó és az Egyesült Államok szomszédosságának, miközben Peru és Chile közös határának hatása a változóra jóval kisebb.
} 


\begin{tabular}{|c|c|c|c|c|c|}
\hline \multirow{2}{*}{ Változó } & \multirow{2}{*}{ Alapmodell } & \multirow{2}{*}{$\begin{array}{l}\text { Bővített } \\
\text { alapmodell }\end{array}$} & \multicolumn{3}{|c|}{ Bővített modell } \\
\hline & & & I. & II. & III. \\
\hline $\ln G D P_{i}$ & $\begin{array}{c}1,13 * * * \\
(341,09)\end{array}$ & $\begin{array}{c}1,19 * * * \\
(239,59)\end{array}$ & $\begin{array}{c}1,19 * * * \\
(241,53)\end{array}$ & $\begin{array}{l}1,27 * * * \\
(27,00)\end{array}$ & $\begin{array}{l}1,14 * * * \\
(19,69)\end{array}$ \\
\hline $\ln G D P_{j}$ & $\begin{array}{c}0,89 * * * \\
(297,84)\end{array}$ & $\begin{array}{c}0,97 * * * \\
(212,78)\end{array}$ & $\begin{array}{c}0,96 * * * \\
(209,95)\end{array}$ & $\begin{array}{l}1,74 * * * \\
(39,94)\end{array}$ & $\begin{array}{l}1,58 * * * \\
(30,35)\end{array}$ \\
\hline $\ln D I S T_{i j}$ & $\begin{array}{c}-0,88^{* * *} \\
(-102,74)\end{array}$ & $\begin{array}{l}-0,85 * * * \\
(-96,34)\end{array}$ & $\begin{array}{l}-0,64 * * * \\
(-68,73)\end{array}$ & $\begin{array}{l}-0,74 * * * \\
(-60,80)\end{array}$ & $\begin{array}{l}-0,74 * * * \\
(-60,73)\end{array}$ \\
\hline $\ln P O P_{i}$ & & $\begin{array}{l}-0,09 * * * \\
(-17,53)\end{array}$ & $\begin{array}{l}-0,09 * * * \\
(-18,30)\end{array}$ & $\begin{array}{l}-0,87 * * * \\
(-6,86)\end{array}$ & $\begin{array}{l}-0,91 * * * \\
(-6,94)\end{array}$ \\
\hline $\ln P O P_{j}$ & & $\begin{array}{l}-0,12 * * * \\
(-23,61)\end{array}$ & $\begin{array}{l}-0,11 * * * \\
(-21,70)\end{array}$ & $\begin{array}{l}-0,87 * * \\
(-8,25)\end{array}$ & $\begin{array}{l}-0,90 * * * \\
(-8,33)\end{array}$ \\
\hline$C O N T_{i j}$ & & & $\begin{array}{c}1,14^{* * * *} \\
(37,25)\end{array}$ & $\begin{array}{l}1,05^{* * * *} \\
(32,37)\end{array}$ & $\begin{array}{l}1,06 \text { **** } \\
(32,61)\end{array}$ \\
\hline$C O M L A N G_{i j}$ & & & $\begin{array}{c}0,94 * * * \\
(52,80)\end{array}$ & $\begin{array}{l}0,95^{* * * *} \\
(51,83)\end{array}$ & $\begin{array}{l}0,95 * * * \\
(52,06)\end{array}$ \\
\hline$F T A_{i j}$ & & & $\begin{array}{l}0,73^{* * *} \\
(45,47)\end{array}$ & $\begin{array}{l}0,68 * * * \\
(40,98)\end{array}$ & $\begin{array}{l}0,65 \text { *** } \\
(38,24)\end{array}$ \\
\hline Konstans & $\begin{array}{l}-26,93 \text { *** } \\
(-192,80)\end{array}$ & $\begin{array}{c}-27,46^{* * * *} \\
(-187,20)\end{array}$ & $\begin{array}{l}-29,35 \text { *** } \\
(-211,20)\end{array}$ & $\begin{array}{l}-24,67 * * * \\
(-13,01)\end{array}$ & $\begin{array}{l}-15,70 * * * \\
(-5,00)\end{array}$ \\
\hline$R^{2}$ & 0,6950 & 0,6982 & 0,7226 & 0,8060 & 0,8072 \\
\hline Kiigazított $R^{2}$ & 0,6950 & 0,6982 & 0,7225 & 0,8057 & 0,8068 \\
\hline Magyarázóváltozók száma (darab) & 3 & 5 & 8 & 168 & 185 \\
\hline Megfigyelések száma (darab) & 89244 & 89244 & 89244 & 89244 & 89244 \\
\hline
\end{tabular}

Megjegyzés. Bővített modell II.: országspecifikus dummy változók; bővített modell III.: ország- és időspecifikus dummy változók.

A bővített modellben a gazdasági méret a LAC6-országok importőrjeinek értékéhez hasonlóan egység körüli koefficienseket eredményezett, miközben a távolság továbbra is közel 50 százalékkal kisebb hatást mutat, mint a korábbi vizsgálatok során. A lakossághoz tartozó változók szignifikáns negatív értéket vesznek fel, hatásuk viszont nem jelentôs. A közös határ és közös nyelv dummy változók szignifikánsan pozitív elöjelet kaptak, a koefficiensek nagysága nem tér el jelentősen a LAC6országokéhoz képest. A szabadkereskedelmi egyezmény hatása azonban mind nagyságban, mind pedig előjelét tekintve jelentősen eltér a korábbi eredményektöl: amíg a LAC6-országoknál a koefficiens értéke a bővített modellben $-0,13$ volt, addig a bövített mintánál ez az érték 0,73 lett. Mindezek alapján jelentős különbséget fedezhe- 
tünk fel a két minta között: amíg a világ legföbb kereskedelmi kapcsolatait tekintve a szabadkereskedelmi egyezmények átlagos hatása szignifikánsan pozitív, illetőleg ez a hatás jelentős mértékü, addig a LAC6-országoknál szignifikánsan negatív és kisebb jelentőségü.

Amennyiben a modellt országspecifikus (exportőr- és importőrspecifikus) dummy változókkal egészítjük ki, annak magyarázóereje kicsivel meghaladja a 80 százalékot, amely hasonló értéket mutat a LAC6-országok esetében is. Országspecifikus változók modellbe helyezésével azok minden együtthatója továbbra is szignifikáns 5 százalékos szinten, a bővített mintához képest jelentősebb mértékben csupán a GDP-hez és a lakossághoz tartozó koefficiensek értéke változott meg.

Időspecifikus dummy változókkal egészítve ki az előző modellspecifikációt csupán minimálisan változnak a korábbi értékek. Az eredmények alapján a globális kereskedelem kevésbé érzékeny a gazdasági méret, a lakosság, illetve a távolság alakulására, mint a latin-amerikai országokat tekintve.

A közös határ a LAC6-országoknál 110 százalékkal növelte az exportot, ez a hatás világviszonylatban már 189 százalékos. Érdekes megfigyelni a jelentős különbséget a közös nyelv tekintetében: amíg világviszonylatban 159 százalékos a hatása, addig a latin-amerikai országok esetében ez az érték jóval alacsonyabb, mindössze 13 százalék. Hasonlóan számottevő a különbség az FTA (free trade agreement szabadkereskedelmi megállapodás) tekintetében is: a latin-amerikai országoknál látott -12 százalékos hatással szemben világviszonylatban 92 százalékos növekedést tapasztalhatunk a közös kereskedelmi megállapodás megléte során.

Az említett különbségeket, illetve a szakirodalom empirikus vizsgálatait tekintve egyetlen változó, az FTA esetében érdemes még a pontos hatás megragadása érdekében javítani a modellspecifikációt. Amennyiben a változót részekre (egyezményekre) bontjuk, és több dummy változót is képzünk, nemcsak ezek, hanem az egyes integrációk hatásait is megragadhatjuk.

\subsection{A regionális kereskedelmi egyezmények hatásának vizsgálata}

Az újabb modellspecifikációban a bővített mintát használva az FTA-t lecseréltem 21 integrációs változóra, melyek 7 regionális integráció hatásait hivatottak megragadni. A vizsgált integrációk a következők: Andok Közösség, ${ }^{13}$ ASEAN (Association of Southeast Asian Nation - Délkelet-ázsiai Nemzetek Szövetség), ${ }^{14}$ CACM, EFTA, EU, Mercosur és NAFTA. A vizsgálatnak nemcsak az a célja, hogy az FTA változó felbontásával pontosabb eredményeket kapjunk a kereskedelmi

\footnotetext{
${ }^{13}$ Bolívia, Kolumbia, Ecuador, Peru.

${ }^{14}$ Fülöp-szigetek, Indonézia, Malajzia, Szingapúr, Thaiföld.
} 
egyezmény befolyásoló erejére vonatkozóan, hanem az is, hogy konkrétan meg lehessen határozni a főbb latin-amerikai integrációk hatásait. Más térségek integrációs változója azért került a modellbe, mert egyrészt ezáltal a modellspecifikációban ki lehet szürni más egyezmények hatását, és így jóval pontosabbak lesznek a latinamerikai integrációkra vonatkozó eredmények, másrészt pedig az európai és ázsiai integrációs eredmények ismertetése összehasonlítási alapot is biztosít.

Az integrációs változók megalkotásakor Carrere [2006] modellspecifikációját követtem, így integrációnként három dummy változó került a modellbe. A hatások vizsgálatához elkülönítettem az integráción belüli kereskedelem vizsgálatát (integráció_intra), az integráción kívüli országokba történő exportot (integráció_export), illetve a harmadik országokból történő importot (integráció_import). A három tényező együttesen határozza meg, hogy egy adott integráció pozitív vagy negatív nettó hatást mutat a vizsgált időszakra vonatkozóan.

Az első modellspecifikáció, a bővített modell eredményei a 4. táblázatban találhatók.

4. táblázat

A föbb RTA-k hatásának vizsgálata gravitációs modellel I.

\begin{tabular}{|c|c|c|c|c|c|}
\hline Változó & $\begin{array}{l}\text { Bővített modell } \\
\text { I. }\end{array}$ & Változó & $\begin{array}{l}\text { Bővített modell } \\
\text { I. }\end{array}$ & Változó & $\begin{array}{l}\text { Bővített modell } \\
\text { I. }\end{array}$ \\
\hline $\ln G D P_{i}$ & $\begin{array}{l}1,28 * * * \\
(190,67)\end{array}$ & ASEAN_export & $\begin{array}{l}1,05^{* * * *} \\
(46,77)\end{array}$ & Mercosur_intra & $\begin{array}{l}1,10 * * * \\
(12,68)\end{array}$ \\
\hline $\ln G D P_{j}$ & $\begin{array}{l}1,00 * * * \\
(173,46)\end{array}$ & ASEAN_import & $\begin{array}{l}0,52^{* * *} \\
(20,41)\end{array}$ & Mercosur_export & $\begin{array}{l}-0,05^{*} \\
(-1,82)\end{array}$ \\
\hline $\ln D I S T_{i j}$ & $\begin{array}{l}-0,68 * * * \\
(-67,59)\end{array}$ & CACM_intra & $\begin{array}{l}3,03^{* * *} \\
(52,89)\end{array}$ & Mercosur_import & $\begin{array}{l}-0,60 * * * \\
(-21,65)\end{array}$ \\
\hline $\ln P O P_{i}$ & $\begin{array}{l}-0,16^{* * * *} \\
(-24,46)\end{array}$ & CACM_export & $\begin{array}{l}-0,25 * * * \\
(-6,65)\end{array}$ & NAFTA_intra & $\begin{array}{l}-0,25 * * \\
(-2,32)\end{array}$ \\
\hline $\ln P O P_{j}$ & $\begin{array}{l}-0,15 * * * \\
(-25,54)\end{array}$ & CACM_import & $\begin{array}{l}-0,08 * * * \\
(-2,72)\end{array}$ & NAFTA_export & $\begin{array}{l}-1,10 * * * \\
(-44,85)\end{array}$ \\
\hline$C O N T_{i j}$ & $\begin{array}{l}1,00 * * * \\
(30,29)\end{array}$ & EFTA_intra & $\begin{array}{l}0,64 * * * \\
(4,62)\end{array}$ & NAFTA_import & $\begin{array}{l}-0,18 * * * \\
(-6,99)\end{array}$ \\
\hline$C O M L A N G_{i j}$ & $\begin{array}{l}1,09 * * * \\
(61,26) \\
\end{array}$ & EFTA_export & $\begin{array}{l}-0,18^{* * *} \\
(-6,03)\end{array}$ & Konstans & $\begin{array}{l}-30,73 * * * \\
(-194,47)\end{array}$ \\
\hline Andok_intra & $\begin{array}{l}1,07 * * * \\
(15,25)\end{array}$ & EFTA_import & $\begin{array}{l}-0,31 * * * \\
(-9,21)\end{array}$ & $R^{2}$ & 0,7422 \\
\hline Andok_export & $\begin{array}{l}-0,33 \text { *** } \\
(-10,61)\end{array}$ & EU_intra & $\begin{array}{l}0,58^{* * * *} \\
(23,49)\end{array}$ & Kiigazított $R^{2}$ & 0,7421 \\
\hline Andok_import & $\begin{array}{l}-0,45^{* * *} \\
(-18,54)\end{array}$ & EU_export & $\begin{array}{c}0,03 * \\
(1,81)\end{array}$ & $\begin{array}{l}\text { Magyarázóváltozók } \\
\text { száma (darab) }\end{array}$ & 28 \\
\hline ASEAN_intra & $\begin{array}{l}2,68 * * * \\
(53,48)\end{array}$ & EU_import & $\begin{array}{l}0,04 * * \\
(2,07)\end{array}$ & $\begin{array}{l}\text { Megfigyelések } \\
\text { száma (darab) }\end{array}$ & 89244 \\
\hline
\end{tabular}


A korábbi bővített minta eredményeihez képest a magyarázóváltozók együtthatói nem mutatnak számottevő változást az FTA integrációs változókkal történő lecserélését követően, miközben a modell magyarázóereje némiképp nőtt. Fix hatások kiszürése nélkül az Andok Közösség, az EU, az EFTA és a Mercosur esetében kismértékü pozitív, az ASEAN-nál és CACM-nál erőteljesen pozitív, a NAFTA-nál pedig negatív az integráció nettó hatása.

Exportőr, importőr és időspecifikus dummy változók modellbe helyezésével (lásd az 5. táblázatot), ezen fix hatások kiszürésével az integrációs változók együtthatói jelentős mértékben változnak, ezáltal sok esetben a korábbi modellspecifikációhoz képest ellentétes következtetésekre juthatunk. Az Andok Közösséget tekintve az egyezmény következtében szignifikánsan nőtt a tagországok közötti kereskedelem, az 1995 és 2012 közötti időszakot vizsgálva ez a hatás közel 500 százalékos. Ezzel szemben a harmadik országokkal folytatott kereskedelemre az egyezmény befolyása nem pozitív: az exportnál az együttható pozitív értéket vesz fel, a hatás viszont statisztikailag nem szignifikáns, az importnál viszont szignifikánsan negatív az eredmény. Összességében nézve az Andok Közösség nettó hatása pozitívnak bizonyul.

Az ASEAN esetében, más empirikus vizsgálatok eredményeihez hasonlóan, eröteljesen szignifikáns pozitív hatást kaptam mindhárom integrációs változónál. Mindezek alapján az ASEAN növelte a tagországok közötti kereskedelmet a legnagyobb mértékben az integrációk közül az 1995 és 2012 közötti időszakra vonatkozóan, miközben a harmadik országokkal folytatott kereskedelem is többszörösére nőtt az időszak alatt, így az egyezmény befolyása egyértelmüen pozitív mind a tagországokra nézve, mind a világ többi országának szempontjából.

A CACM-országok kereskedelme szignifikáns növekedést mutat, ezzel szemben a harmadik országokkal folytatott kereskedelem mind az export, mind az import tekintetében csökkent, bár az import esetében a hatás nem szignifikáns. Összességében az integráció befolyása kis mértékben, de pozitív.

Az EFTA a korábbi modellspecifikáció eredményével szemben szignifikáns negatív hatást mutat a tagországok közötti kereskedelemre, illetve a harmadik országok felé irányuló exportra, miközben a nem tagországokból származó import együtthatója ugyan szintén negatív, viszont nem szignifikáns értéket vesz fel. Az EFTA negatív következményekkel jár az integráción belüli és kívüli országokra nézve egyaránt.

Az EU-nál az integráción belüli kereskedelem szignifikáns pozitív értéket mutat, a harmadik országokba irányuló export is pozitív irányba nőtt az integrációnak köszönhetően, viszont az import esetében ez a változás már nem szignifikáns. A teljes hatást tekintve az Európai Unió pozitívan befolyásolja mind a tagországok, mind pedig a harmadik országok kereskedelmét.

A Mercosur esetében statisztikailag szignifikáns negatív hatást láthatunk az integráción belüli kereskedelmet vizsgálva, valamint az integráción kívüli országokkal 
folytatott export és import tekintetében is, így a Mercosur hatása egyértelmüen negatív a tagországok, illetve az integráción kívüli országok számára is.

A föbb RTA-k hatásának vizsgálata gravitációs modellel II.

\begin{tabular}{|c|c|c|c|c|c|}
\hline Változó & $\begin{array}{l}\text { Bővített modell } \\
\text { II. }\end{array}$ & Változó & $\begin{array}{l}\text { Bővített modell } \\
\text { II. }\end{array}$ & Változó & $\begin{array}{l}\text { Bövített modell } \\
\text { II. }\end{array}$ \\
\hline $\ln G D P_{i}$ & $\begin{array}{l}1,07 * * * \\
(17,96)\end{array}$ & ASEAN_export & $\begin{array}{l}2,45^{* * *} \\
(16,15)\end{array}$ & Mercosur_intra & $\begin{array}{l}-1,04 * * \\
(-2,32)\end{array}$ \\
\hline $\ln G D P_{j}$ & $\begin{array}{l}1,55^{* * * *} \\
(29,15)\end{array}$ & ASEAN_import & $\begin{array}{l}1,20 * * * \\
(12,00)\end{array}$ & Mercosur_export & $\begin{array}{l}-1,28 * * * \\
(-3,24)\end{array}$ \\
\hline $\ln D I S T_{i j}$ & $\begin{array}{l}-0,76^{* * * *} \\
(-61,03)\end{array}$ & CACM_intra & $\begin{array}{l}1,84 * * * \\
(4,77)\end{array}$ & Mercosur_import & $\begin{array}{l}-1,42 * * * \\
(-5,39)\end{array}$ \\
\hline $\ln P O P_{i}$ & $\begin{array}{l}-0,77 * * \\
(-5,30)\end{array}$ & CACM_export & $\begin{array}{l}-1,51 * * * \\
(-5,10)\end{array}$ & NAFTA_intra & $\begin{array}{l}2,38 * * * \\
(4,83)\end{array}$ \\
\hline $\ln P O P_{j}$ & $\begin{array}{l}-1,04 * * * \\
(-8,86)\end{array}$ & CACM_import & $\begin{array}{c}-0,04 \\
(-0,17)\end{array}$ & NAFTA_export & $\begin{array}{l}1,67 * * * \\
(4,60)\end{array}$ \\
\hline$C O N T_{i j}$ & $\begin{array}{l}0,92^{* * * *} \\
(28,09)\end{array}$ & EFTA_intra & $\begin{array}{l}-1,15^{* * * *} \\
(-2,95)\end{array}$ & NAFTA_import & $\begin{array}{c}-0,20 \\
(-0,67) \\
\end{array}$ \\
\hline$C O M L A N G_{i j}$ & $\begin{array}{l}0,95^{* * * *} \\
(51,57) \\
\end{array}$ & EFTA_export & $\begin{array}{c}-0,23 \\
(-0,82)\end{array}$ & Konstans & $\begin{array}{l}-12,99 * * * \\
(-3,96)\end{array}$ \\
\hline Andok_intra & $\begin{array}{l}1,79 * * * \\
(11,67)\end{array}$ & EFTA_import & $\begin{array}{l}-1,94 * * * \\
(-8,75)\end{array}$ & $R^{2}$ & 0,8081 \\
\hline Andok_export & $\begin{array}{r}0,07 \\
(0,57)\end{array}$ & EU_intra & $\begin{array}{l}0,64 * * * \\
(15,17)\end{array}$ & Kiigazított $R^{2}$ & 0,8076 \\
\hline Andok_import & $\begin{array}{l}-0,16^{* *} \\
(-2,51)\end{array}$ & EU_export & $\begin{array}{l}0,23 * * * \\
(7,16)\end{array}$ & $\begin{array}{c}\text { Magyarázóváltozók } \\
\text { száma (darab) }\end{array}$ & 193 \\
\hline ASEAN_intra & $\begin{array}{l}4,60 * * * \\
(24,79)\end{array}$ & EU_import & $\begin{array}{c}0,05 \\
(1,59)\end{array}$ & $\begin{array}{l}\text { Megfigyelések } \\
\text { száma (darab) }\end{array}$ & 89244 \\
\hline
\end{tabular}

Megjegyzés. Bővített modell II.: exportőr- és importőr-specifikus, valamint időspecifikus dummy változókkal.

A NAFTA figyelembevételével az ország- és időspecifikus fix hatások kiszürésével az integrációs változók előjele megváltozott, a végső modellspecifikáció eredményeit tekintve mind a tagországok közötti, mind pedig a harmadik országokkal folytatott kereskedelem pozitív irányba változott az egyezmény következtében, habár a harmadik országokból érkező importhoz tartozó együttható negatív előjelet vesz fel, statisztikailag viszont nem szignifikáns.

Mindezek alapján elmondható, hogy a latin-amerikai országokat tartalmazó integrációk közül egyedül a NAFTA esetében mutatható ki a világ minden országa számá- 
ra pozitív hatás, az Andok Közösség és a CACM csupán a tagországok közötti kereskedelmet befolyásolták pozitívan, miközben a Mercosur az integráción belüli, illetve a harmadik országokat érintően is egyértelmüen negatívan.

\section{Következtetések}

A tanulmányban gravitációs modell segítségével sikerült rámutatni a LAC6országok külkereskedelmét leginkább befolyásoló tényezőkre. Az eredmények alapján a gazdasági méret pozitív, a távolság pedig negatív hatással van ezen országok bilaterális kereskedelmére, miközben a közös határ, nyelv és a kereskedelmi egyezmény megléte is jelentős szerepet játszik az export alakulásában.

Ország- és időspecifikus fix hatások kiszürésével a kapott eredmények alapján arra a következtetésre juthatunk, hogy - a gazdasági méret hatását kiszürve - két egyforma távolságra helyezkedő ország közül a LAC6-országok ceteris paribus az OECD-országba fognak többet exportálni, miközben a közös nyelv és határ meglétekor is az OECD-országokba érkezne több export.

A XX. század során a technológiai fejlődésnek köszönhetően a földrajzi távolságok megtétele fokozatosan egyszerübbé, gyorsabbá és nem utolsó sorban olcsóbbá is vált, és ezen folyamatok a XXI. században a fejlettebb szállítási és kommunikációs eszközök nyomán tovább folytatódtak. Empirikus vizsgálatok bizonyítják, hogy napjainkra a távolság kereskedelmet csökkentő szerepe erőteljesen visszaesett az említett folyamatoknak köszönhetően (Brun et al. [2012]), azonban ez a csökkenés, ahogy a távolság abszolút értelemben vett, kereskedelemre gyakorolt hatása is, országonként és térségenként változó, melyet a kutatás empirikus eredményeiben rejlő különbségek is alátámasztanak. A LAC6-országok exportjának gravitációs vizsgálata, illetve az érzékenységvizsgálatok eredményei alapján megállapítható, hogy a LAC6-országok külkereskedelme sokkal érzékenyebb az országok közötti bilaterális távolság alakulására, mint a globális átlag.

A bővített minta a globális adatsor következtében arra is lehetőséget nyújtott, hogy mélyebben is megvizsgálhassuk a napjainkra kereskedelempolitikai szempontból egyre nagyobb jelentőségüvé váló tényező, a szabadkereskedelmi megállapodás hatásait. A korábbi modellspecifikációkban használt bináris változót integrációnkénti változóval cseréltem le, miközben Carrere [2006] nyomán integrációnként dummy változókat képeztem a tagországon belüli és harmadik országokkal folytatott kereskedelem alakulásának megfigyelésére. Az eredmények alapján a latin-amerikai országot nem tartalmazó EU és ASEAN nettó hatása pozitívnak bizonyult, mely eredmény megegyezik más empirikus vizsgálatok eredményeivel 
(Martinez-Zarzoso [2003], Jugurnath-Stewart-Brooks [2007], Barbalet et al. [2015]; Rose-van Wincoop [2001], Geldi [2012], Coulibaly [2009], MacPheeSattayanuwat [2014], Guilhot [2010]). A latin-amerikai országokat tartalmazó integrációk sorában a Mercosur hatása egyértelműen negatív az integráción belüli és a harmadik országokkal folytatott kereskedelem esetében is, ezzel szemben az Andok Közösség és a CACM pozitív hatást gyakorolt a tagországok közötti kereskedelemre, miközben a pozitív hatás a NAFTA tekintetében a világ minden országa számára kimutatható.

Az empirikus vizsgálat eredményei alapján számos gazdaság- és kereskedelempolitikai következtetést lehet levonni. Ilyen például az infrastrukturális beruházások és fejlesztések fontossága a térség országai számára, hiszen a kapott eredmények alapján a LAC6-országok külkereskedelme szignifikánsan érzékenyebb a távolság növekedésére, mint a globális átlag. A szállítási infrastruktúra fejlesztésével nem csupán világviszonylatban csökkenhetne a távolság negatív hatása a külkereskedelemre, hanem a térségen belüli kereskedelem szintjére is pozitív befolyást gyakorolhatna. Másik jelentős kereskedelempolitikai következtetés az empirikus gravitációs eredményeket tekintve, hogy szükséges újragondolni a latin-amerikai regionális integrációk működését, ugyanis a kapott eredmények alapján nem egyértelmü ezen egyezmények pozitív hatása. Szorosabb gazdasági és politikai együttműködéssel, hatékonyabb intézményekkel jelentősebb előnyökre tehetnének szert ezek az országok, például az integráción belüli közös agrárpolitikával méretgazdaságossági előnyöket lehetne kiaknázni, közös infrastrukturális beruházásokkal vagy üzleti szabályozással pedig jelentősen növekedhetne az integráción belüli országok versenyképessége.

\section{Irodalom}

Aitken, N. D. [1973]: The effect of the EEC and EFTA on European trade: A temporal crosssection analysis. The American Economic Review. Vol. 63. No. 5. pp. 881-892.

ANDERLE Á. [2010]: Latin-Amerika története. Második javított és bővített kiadás. Pannonica Kiadó. Budapest.

ANDERSON, J. E. [1979]: A theoretical foundation for the gravity equation. The American Economic Review. Vol. 69. No. 1. pp. 106-116.

Anderson, J. E. [2010]: The Gravity Model. Working Paper No. 16576. National Bureau of Economic Research. Cambridge.

Anderson, J. E. - Marcouiller, D. [2002]: Insecurity and the pattern of trade: An empirical investigation. Review of Economics and Statistics. Vol. 84. No. 2. pp. 342-352. http://dx.doi.org/10.1162/003465302317411587

Anderson, J. E. - Van Wincoop, E. [2001]: Gravity with Gravitas: A Solution to the Border Puzzle. Working Paper. No. 8079. National Bureau of Economic Research. Cambridge. 
Anderson, J. E. - Yotov, Y. V. [2011]: Terms of Trade and Global Efficiency Effects of Free Trade Agreements, 1990-2002. Working Paper No. 17003. National Bureau of Economic Research. Cambridge.

BAIER, S. L. - BERGSTRAND, J. H. [2007]: Do free trade agreements actually increase members' international trade? Journal of International Economics. Vol. 71. No. 1. pp. 72-95. http://dx.doi.org/10.1016/j.jinteco.2006.02.005

Barbalet, F. - Greenville, J. - Crook, W. - Gretton, P. - Breunig, R. [2015]: Exploring the links between bilateral and regional trade agreements and merchandise trade. Asia and the Pacific Policy Studies. Vol. 2. No. 3. pp. 467-484. http://dx.doi.org/10.1002/app5.101

Brun, J.-F. - Carrére, C. - Guillaumont, P. - De Melo, J. [2005]: Has distance died? Evidence from panel gravity model. The World Bank Economic Review. Vol. 19. No. 1. pp. 99-120. http://dx.doi.org/10.1093/wber/lhi004

CARRERE, C. [2006]: Revisiting the effects of regional trade agreements on trade flows with proper specification of the gravity model. European Economic Review. Vol. 50. No. 2. pp. 223-247. http://dx.doi.org/10.1016/j.euroecorev.2004.06.001

Coulibaly, S. [2009]: Evaluating the trade effect of developing regional trade agreements: A semi-parametric approach. Journal of Economic Integration. Vol. 24. No. 4. pp. 709-743. http://dx.doi.org/10.11130/jei.2009.24.4.709

De Groot, H. L. - Linders, G. J. - Rietveld, P. - Subramanian, U. [2004]: The institutional determinants of bilateral trade patterns. Kyklos. Vol. 57. No. 1. pp. 103-123. http://dx.doi.org/10.1111/j.0023-5962.2004.00245.x

EicheR, T. S. - HenN, C. - PAPAgeorgiou, C. [2012]: Trade creation and diversion revisited: Accounting for model uncertainty and natural trading partner effects. Journal of Applied Econometrics. Vol. 27. No. 2. pp. 296-321. http://dx.doi.org/10.1002/jae.1198

Felbermayr, G. - Toubal, F. [2007]: Cultural Proximity and Trade. SSNR. New York. http://dx.doi.org/10.2139/ssrn.1133987

Frankel, M. J. A. - WeI, S. J. [1998]: Open Regionalism in a World of Continental Trade Blocs. Working Paper No. 10. International Monetary Fund. Washington, D.C. http://dx.doi.org /10.5089/9781451842661.001

GELDI, H. K. [2012]: Trade effects of regional integration: A panel cointegration analysis. Economic Modelling. Vol. 29. No. 5. pp. 1566-1570. http://dx.doi.org/10.1016/ j.econmod.2012.05.017

Guilhot, L. [2010]: Assessing the impact of the main East-Asian free trade agreements using a gravity model. First results. Economics Bulletin. Vol. 30. No. 1. pp. 282-291.

HEAD, K. [2003]: Gravity for Beginners. University of British Columbia. Vancouver.

HEAD, K. - MAYER, T. - RIES, J. [2010]: The erosion of colonial trade linkages after independence. Journal of International Economics. Vol. 81. No. 1. pp. 1-14. http://dx.doi.org/10.1016 j.jinteco.2010.01.002

Hutchinson, W. K. [2002]: Does ease of communication increase trade? Commonality of language and bilateral trade. Scottish Journal of Political Economy. Vol. 49. No. 5. pp. 544556. http://dx.doi.org/10.1111/1467-9485.00247

Jugurnath, B. - Stewart, M. - Brooks, R. [2007]: Asia/Pacific regional trade agreements: An empirical study. Journal of Asian Economics. Vol. 18. No. 6. pp. 974-987. http://dx.doi.org/10.1016/j.asieco.2007.09.003 
Linnemann, H. [1966]: An Econometric Study of International Trade Flows. North-Holland Publishing Company. Amsterdam.

Macphee, C. R. - Sattayanuwat, W. [2014]: Consequence of regional trade agreements to developing countries. Journal of Economic Integration. Vol. 29. No. 1. pp. 64-94. http://dx.doi.org/10.11130/jei.2014.29.1.64

Martinez-Zarzoso, I. [2003]: Gravity model: An application to trade between regional blocs. Atlantic Economic Journal. Vol. 31. Issue 2. pp. 174-187. http://dx.doi.org/10.1007/BF02319869

Mayer, T. - Zignago, S. [2005]: Market Access in Global and Regional Trade. Working Paper. No. 2. Centre d'Études Prospectives et d'Informations Internationales. Paris.

MCCALlum, J. [1995]: National borders matter: Canada-US regional trade patterns. The American Economic Review. Vol. 85. No. 3. pp. 615-623.

OH, C. H. - Selmier, W. T. - LIEN, D. [2011]: International trade, foreign direct investment, and transaction costs in languages. The Journal of Socio-Economics. Vol. 40. No. 6. pp. 732-735. http://dx.doi.org/10.1016/j.socec.2011.08.003

PÖSTÉNYI A. [2016]: A 6 legnagyobb latin-amerikai ország külkereskedelmének vizsgálata gravitációs modellel. PhD-értekezés. Debreceni Egyetem. Debrecen.

Rahman, M. M. [2003]: A Panel Data Analysis of Bangladesh's Trade: The Gravity Model Approach. Proceedings of the $5^{\text {th }}$ Annual Conference of the European Trade Study Group. European Trade Study Group. Madrid. pp. 1-54.

Ravenstein, E. G. [1889]: The Laws of Migration. Journal of the Royal Statistical Society. Vol. 52. No. 2. pp. 241-305. http://dx.doi.org/10.2307/2979333

RoSE, A. K. - VAN WINCOOP, E. [2001]. National money as a barrier to international trade: The real case for currency union. The American Economic Review. Vol. 91. No. 2. pp. 386-390. http://dx.doi.org/10.1257/aer.91.2.386

Schumacher, D. [2003]: Home Market and Traditional Eon Comparative Advantage in a Gravity Approach. Discussion Paper No. 344. German Insitute for Economic Research. Berlin.

Shirotori, M. - Tumurchudur, B. - CADOT, O. [2010]: Revealed Factor Intensity Indices at the Product Level. United Nations. New York, Geneva.

Shujiro, U. - MisA, O. [2007]: The Impacts of Free Trade Agreements on Trade Flows: An Application of the Gravity Model Approach. Discussion Paper No. 07-E-052. Research Institute of Economy, Trade and Industry. Tokyo.

SoHN, C. H. [2005]: Does the gravity model explain South Korea's trade flows? Japanese Economic Review. Vol. 56. No. 4. pp. 417-430. http://dx.doi.org/10.1111/j.14685876.2005.00338.x

Soloaga, I. - Winters, L. A. [2001]: Regionalism in the nineties: What effect on trade? The North American Journal of Economics and Finance. Vol. 12. No. 1. pp. 1-29. http://dx.doi.org/10.1016/S1062-9408(01)00042-0

TinBERgEn, J. [1962]: Shaping the World Economy: Suggestions for an International Economic Policy. Twentieth Century Fund. New York.

VICARD, V. [2009]: On trade creation and regional trade agreements: Does depth matter? Review of World Economics. Vol. 145. No. 2. pp. 167-187. http://dx.doi.org/10.1007/s10290-009-0010-9

VINER, J. [1950]: The Customs Union Issue. Carnegie. New York.

WEI, S. J. [1996]: Intra-National versus International Trade: How Stubborn are Nations in Global Integration? Working Paper. No. 5531. National Bureau of Economic Research. Cambridge. 


\section{Summary}

The study focuses on the exports of LAC6 countries (Argentina, Brazil, Chile, Colombia, Mexico, and Peru), the six largest economies in Latin America, using the gravity model of trade. Paying particular attention to the impact of regional trade integrations, it determines the main factors influencing exports in LAC6 countries. The results show significant variations in bilateral trade with OECD and non-OECD countries, while regarding the results of the expanded sample, significant differences from the world average can be detected as well, mainly in geographical distance, common language and free trade agreements. When analysing the effects of regional trade integrations, only NAFTA shows signs of positive effects for all the countries in the sample as regards the integrations containing Latin American countries; the Andean Community and CACM (Central American Common Market) have only positive effects on the member states, while in the case of Mercosur, the effects of intra-integration trade as well as trade with third countries are negative. 